\title{
Why am I determined to be a doctor in China?
}

\section{Dongquan Shi}

State Key Laboratory of Pharmaceutical Biotechnology, Department of Sports Medicine and Adult Reconstructive Surgery, Nanjing Drum Tower Hospital, The Affiliated Hospital of Nanjing University Medical School, Nanjing, China

Correspondence to: Dongquan Shi, MD, PhD. State Key Laboratory of Pharmaceutical Biotechnology, Department of Sports Medicine and Adult Reconstructive Surgery, Nanjing Drum Tower Hospital, The Affiliated Hospital of Nanjing University Medical School, 321 Zhongshan Road, Nanjing 210008, China. Email: shidongquan@nju.edu.cn.

Submitted Jul 23, 2020. Accepted for publication Jan 10, 2021.

doi: $10.21037 /$ atm-20-5487

View this article at: http://dx.doi.org/10.21037/atm-20-5487

I am writing this letter to you for sharing my career story, and I hope this letter will bring inspiration and courage to medical students or young doctors that just begun their medical career.

Before taking the college entrance examination in 1999, I aspired to be an automotive engineer, as I wanted the opportunity to participate in the manufacture of the best automobiles in the world. However, at that time, only Tsinghua University and Shanghai Jiao Tong University had established automobile engineering majors, and my school record was quite mediocre. Although I believed my chances were the slim, I continued to strive towards this goal. After taking the college entrance exam, I estimated that my score would be 631, but in fact, my score was just 625 . When pre-filling the college entrance preference form for majors, I chose automotive engineering without hesitation, and yet when it came to the real thing, I picked medicine. The reason for this decision might be that my father had been suffering from Parkinson's disease, and this made me want to relieve not just his suffering, but that of all people, using my own effort. Looking back, if could choose again, I would make the same choice.

\section{The following key words have informed my career as an orthopedist: sense of achievement, happiness, and value}

\section{Sense of achievement}

This key phrase almost accompanies a doctor's whole life. When I was a resident doctor in internship rotation, a patient came to me complaining about his long hospital stay due to repeated infections and unhealed incisions. At first, this patient didn't trust me because of my internship status; I could feel it from his eyes and words, but this made me more careful and earnest when I changed the dressing for his wound. Each time, I would thoroughly clean up the necrotic tissue on the incision edge, only leaving fresh and tender granulation, and each time I would put myself in his position and attempt to explain the potential causes of his condition in plain words. About one month later, his incision had healed nicely.

The patient and his wife were disadvantaged and depended on each other for their lives. One was a barber with a disability, and the other helped out with some chores. The whole family relied on the hairdressing trade. After my repeated discussions and explanations given to the family, the patient was finally satisfied and agreed to be discharged. Before being released from hospital, he left me a note (Figure 1). Despite several incorrectly written characters, I was deeply moved by the sincere feelings conveyed by it. As a resident doctor who had just begun his medical career, receiving the note evoked an indescribable sense of achievement and warmth in my heart.

After I could conduct surgery independently, I met a young patient in his 20s. He was in the prime of his life, but because of ankylosing spondylitis and subsequent bilateral hip fusion, he was bedridden and had to endure tremendous pain. After dislocation, one of his hip joints had fused with the ilium. Fortunately, after we treated him using bilateral hip arthroplasty, he was finally able to stand on his own. When he came to my clinic for a post-operative review, he was very happy and proud to tell me: "Look, Dr. Shi. 


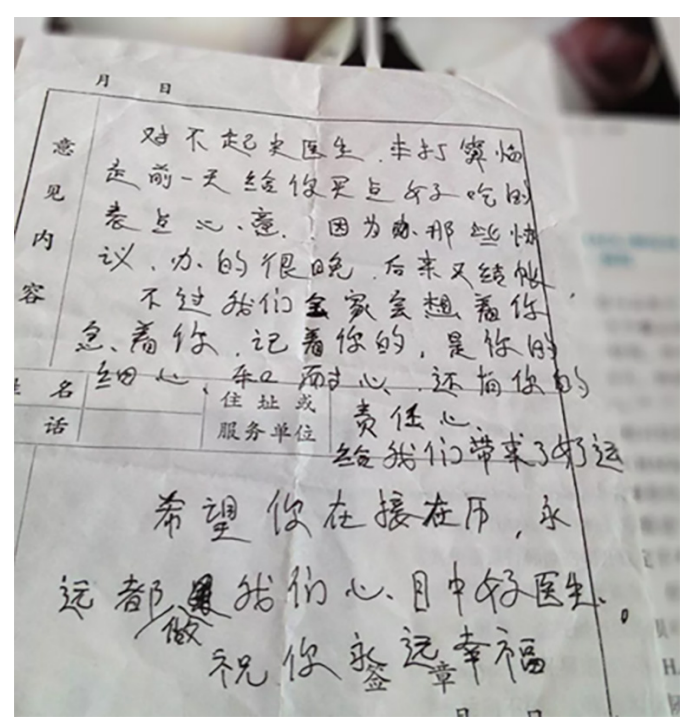

Figure 1 A note left for me by the patient before discharge. The words in the note means: "I'm sorry for misunderstanding you, Dr. Shi. I would have bought you some presents before I left, if the discharge procedures weren't so late and the inpatient checkout later didn't take so much time. At all events, our whole family will miss and remember you. Thanks for your carefulness, patience, and responsibility that brought us good fortune. I hope you will keep working hard. You will always be a good doctor in our hearts. Best wishes, always."

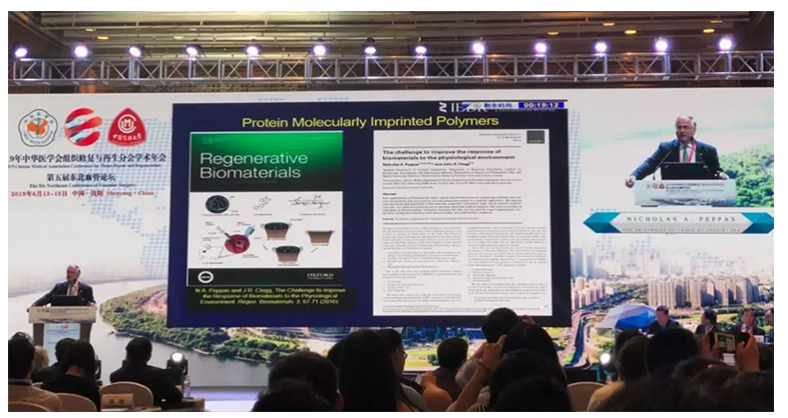

Figure 2 A figure from our research is shown in a conference report.

I can walk by myself now!" I noticed his single mother's tearful smile, and as a surgeon, I will remember the sense of accomplishment I felt at this moment for the rest of my life.

These kinds of stories happen every day. I believe that every orthopedist has a similar sense of achievement of "dreams turning into reality" when they see patients who can walk with the vigor of healthy people. Indeed, all doctors at my center, from the neurosurgery to the cardiothoracic surgery to the emergency departments and ICU, must feel a sense of accomplishment beyond words when they manage to restore patients with their own hands.

Another source of sense of achievement for doctors is solving clinical problems scientifically. For surgery involving joints, the greatest challenge is the repair of the articular cartilage defects. After 5 years of hard work, our team invented a cartilage repair strategy, which is superior to those previously reported, and can be applied to our patients in the near future to assist them to walk. In addition, our new repair strategy can also reduce treatment costs by two-thirds. Moreover, this liquid scaffold can be deployed in cartilage defects of any shape, and at the same time, has the ability to keep releasing drugs for 2 months in the defect area. It was at the time when I noticed the figures in our papers were widely cited by peers, I realized that as long as we diligently and seriously work on an issue, it will ultimately be discovered and recognized by the public (Figure 2). In our research, we have screened susceptibility genes of osteoarthritis, hip dysplasia, and other diseases, and the high-risk population of thrombosis after joint replacement, and explored better hemostatic drug administration schemes. Each discovery has promise in helping patients reduce the distress of diseases and brings them new hope.

\section{Happiness}

The path to studying medicine requires passion. If you are in this profession and have no passion for it, your life will be full of complaints, which will affect you and your family. However, with passion, this profession offers happiness all along its path. There are many sources of happiness: the recovery of patients, the publication of papers, the application of patents, the development of new technologies, the dissemination of knowledge, the recognition of peers, the praise of supervisors, the admiration of students, and so on. I still remember a patient, who, just as their operation was beginning, went into abrupt respiratory and cardiac arrest, and thus our entire anesthesia team persisted in performing cardiopulmonary resuscitation for at least 50 minutes, without giving up. At last, the patient miraculously survived. The moment the resuscitation team saw the patient's heart rate, respiration rate, blood pressure, and blood oxygen saturation return to normal, the members 
embraced each other, and could not hold back the excitement in their eyes. This kind of deep-rooted happiness may be beyond that found in any other profession.

For me, there is also a part of happiness that comes from "the happy academic". Four years ago, I initiated and led the establishment of the Youth Joint Surgeons' Happiness-gathering Club of Jiangsu Province. The purpose of the "Happiness-gathering Club" was a to enable young joint surgeons in Jiangsu to gather and be happy together. Many people may think that it's boring to study medicine, probably because they hardly talk to and learn of the happiness their peers experience on this path. There are nearly 800 members in the club, covering $80 \%$ of the young joint surgeons in class 2 and 3 hospitals in Jiangsu Province, and more than 10,000 young surgeons can receive education and training every year. Doctors might think they are alone in the long journey studying medicine in silence and dullness, but when they find that there is a group of young joint surgeons who can "hold" together, the joy of camaraderie and the comfort of common experiences emerges.

One particularly happy moment occurred when a friend in the club said his wife found he had changed. He would participate in the study and discussion of trivial knowledge and cases in the Wechat group every day, rather than his usual going out at night for entertainment. Our club has gradually expanded to the whole country, and the Youth Orthopaedists Union of Wu Jieping Medical Foundation was finally established, so that even more young orthopedic peers could feel the warmth of being among other happy academics. "One Tree" Cafe in Beijing is also full of joyous laughter and cheerful voices every week because the "One Tree Class" has become a successful brand. There are volunteer professors to share experiences and communicate with each other every week, so that doctors pursuing further training in Beijing will not feel lonely, and enjoy the time of "happy surgery, happy academic" together. I think these groups exist in every specialty, spreading the charm and happiness of medicine.

\section{Value}

Your value to society rapidly increases after taking your first step into medicine. Your patients, your family, your relatives, your friends, and their relatives or friends all need you. Not only that, all of them may "take orders" from their social network, which gradually weaves a huge social resource network for you. Two nights ago, a friend of mine entrusted me with one of his relatives, who was suspected of having myocardial infarction, so that he could work without any worries as he was busy with Nanjing Innovation Week activities. Indeed, when you encounter different kinds of difficulties, there will be a number of people willing to give you a hand as well. Seeing others be relieved of pain and become happier with your help, allows your individual value to be fully realized.

Beside this, we young and middle-aged orthopedists gather together and make the use of our fragmented time to donate resources on the grass-roots level, bringing advanced concepts and technologies to local hospitals and doctors, so that people there can enjoy the high-quality medical resources of class 3 Grade A hospitals without making a long journey. By "gathering to be flame, scattering to be stars", through pooling everyone's value together, we young doctors can make our contribution to solve the imbalance of medical resources in China.

Life is so precious, and so doctors should be given their due respect. With the continuous improvement of the medical environment and the evolution of the medical ecology, becoming a doctor is undoubtedly the first choice for the brave.

\section{Acknowledgments}

Thanks to Dr. Guo Hu and J. Gray for editing the article. Funding: None.

\section{Footnote}

Provenance and Peer Review: This article was a standard submission to the journal. The article did not undergo external peer review.

Conflicts of Interest: The author has completed the ICMJE uniform disclosure form (available at http://dx.doi. org/10.21037/atm-20-5487). DS serves as an unpaid Associate Editors-in-Chief of Annals of Translational Medicine from Jun 2019 to May 2024.

Ethical Statement: The author is accountable for all aspects of the work in ensuring that questions related to the accuracy or integrity of any part of the work are appropriately investigated and resolved. 
Open Access Statement: This is an Open Access article distributed in accordance with the Creative Commons Attribution-NonCommercial-NoDerivs 4.0 International License (CC BY-NC-ND 4.0), which permits the noncommercial replication and distribution of the article with the strict proviso that no changes or edits are made and the original work is properly cited (including links to both the formal publication through the relevant DOI and the license). See: https://creativecommons.org/licenses/by-nc-nd/4.0/.

Cite this article as: Shi D. Why am I determined to be a doctor in China? Ann Transl Med 2021;9(9):816. doi: 10.21037/ atm-20-5487 